УДК $373.31 ; 378.14 ; 376.3$

Косова Катерина Олексіївна, старший викладач кафедри прикладної математики Таврійського національного університету ім. В. І. Вернадського, м. Сімферополь

\title{
ТИФЛОІНФОРМАЦЙНІ КОМПЕТЕНТНОСТІ СУЧАСНОГО ВЧИТЕЛЯ ПОЧАТКОВИХ КЛАСІВ
}

\begin{abstract}
Анотація
Тенденції до навчання дітей 3 порушенням зору в масових школах 3 використанням інформаційно-комунікаційних технологій (IКТ) висувають певні вимоги до відповідної підготовки вчителів початкових класів. Метою статті є аналіз підходів до формулювання поняття компетенціі//компетентності в галузі ІКТ 3 наступним визначенням змісту спеціальних компетентностей учителів початкових класів, які пропонується назвати тифлоінформаційними. На підставі аналізу літератури, зроблено висновок про відсутність у змісті IKTкомпетенцій/компетентностей, пов'язаних із суб'єктом навчання з порушенням зору i сформульовано перелік тифлоінформаційних компетентностей учителя початкових класів. Завданням для подальших досліджень $є$ розробка методик формування відповідних компетентностей.

Ключові слова: компетентності у сфері ІКТ, діти з порушенням зору, учителі початкових класів, тифлоінформаційні компетентності.

Сучасні підходи до надання освіти особам з обмеженими можливостями, зокрема, з порушенням зору, грунтуються на інтегрованому навчанні та інклюзії дітей з вадами здоров'я у звичайні класи масових шкіл [1-3 та ін.]. Наявність цих тенденцій обумовлює нові вимоги до рівня підготовки вчителів.

На перший ступінь навчання (1-4 класи) припадає період адаптації дитини до нового соціального середовища й інтенсивного формування психічних механізмів. Потреба в спеціальному, корекційно-спрямованому дидактичному підході в цьому віці відчувається особливо гостро [наприклад, 4]. Нестача сертифікованих фахівців, які здатні супроводжувати процес навчання дітей 3 порушенням зору, створює передумови для нарощування компетентнісного потенціалу вчителів загального профілю. У цих умовах, одним із першочергових завдань стає формування i
\end{abstract}


розвинення професійних здатностей учителів початкових класів у галузі навчання дітей з ослабленим зором.

Сучасні автори [4-6 та ін.] сходяться в думці, що використання інформаційнокомунікаційних технологій (IКТ) дозволяє будувати принципово нові шляхи навчання дітей з фізичними відхиленнями, зокрема, з порушенням зору, мотивувати дитину в навчанні, проектувати зміст навчання, який неможливий без комп'ютерних технологій, максимально індивідуалізувати навчання дитини.

Отже, особливу актуальність набуває питання підготовки вчителів початкових класів до використання IКТ у навчанні дітей з порушенням зору.

Метою цієї статті $€$ аналіз підходів до формулювання поняття компетенції/компетентності в галузі IKT із наступним визначенням змісту спеціальних компетентностей учителів початкових класів, які пропонується назвати тифлоінформаційними.

У сучасній літературі компетенція й/або компетентність у галузі ІКТ мають різні назви: інформаційна, комп'ютерна, інформаційно-комунікаційна, інформатична та ін. Однак при ближчому розгляді виявляється спорідненість, а іноді й ідентичність у трактуванні цих визначень.

Оцінка понять ускладнюється завзятим бажанням багатьох авторів [7-11 та ін.] використовувати слово «інформація» як сурогат понять «матеріали», «відомості», «знання» тощо. Водночас, іншими дослідниками [12-15] показана некоректність подібних лексичних замін. Вичерпні пояснення з цього питання містяться в роботах М. I. Жалдака $[12,13]$. Далі слово «інформація» буде використовуватися винятково для збереження оригінальності авторських рядків.

Відповідно до визначення О. Л. Семенова (2000), інформаційна компетентність — це «нова грамотність», що включає вміння людини активно й самостійно обробляти «інформацію» та приймати рішення в непередбачених ситуаціях за допомогою технічних засобів [10]. У роботі О. Б. Зайцевої (2002) інформаційна компетентність трактується як результат інтегрування теоретичних знань, практичних умінь в галузі ІКТ й особистісних якостей [16]. С. В. Тришина й А. В. Хуторський (2004) виділяють такі завдання для ключової інформаційної компетентності фахівця в системі додаткової фахової освіти: 
- збагачення знаннями й уміннями з галузі інформатики й інформаційнокомунікаційних технологій;

• розвиток комунікативних, інтелектуальних здатностей;

- зіійснення інтерактивного діалогу в єдиному інформаційному просторі [17].

До переліку інформаційних компетенцій А. В. Хуторський (2005) додає навички діяльності, яка стосується інформації, у навчальних предметах, освітніх галузях та навколишньому світі, у тому числі, володіння такими IКТ, як аудіо- i відеозапис, електронна пошта й Інтернет [7].

О. М. Науменко (2009), розглядаючи інформаційну компетентність як складову загальної професійної компетентності вчителя, розкриває зміст поняття в так:

• «здатність до самостійного пошуку та обробки інформації, що необхідна для якісного виконання професійних завдань;

- готовність до роботи в групі та співробітництва 3 використанням сучасних інформаційно-комунікаційних технологій з метою досягнення професійно значущих цілей і завдань;

- спрямованість на саморозвиток, постійне підвищення кваліфікації у галузі інформаційних технологій, самореалізація в професійній діяльності» [18].

С. М. Литвинова (2008) визначає інформаційну компетентність «як здатність особистості орієнтуватися в потоці інформації, як уміння працювати 3 різними видами інформації, знаходити і відбирати необхідний матеріал, класифікувати його, узагальнювати, критично до нього ставитися, на основі здобутих знань вирішувати будь-яку інформаційну проблему, пов’язану 3 професійною діяльністю» [8]. Розвиваючи тему професіоналізму педагога, автор розглядає три складові поняття інформаційно-комунікаційної компетентності вчителя-предметника:

- загальна компетентність (здатність використовувати IКТ для забезпечення навчально-виховного процесу, у тому числі, розробляти власні електронні продукти);

- $\quad$ діагностична компетентність (здатність аналізувати досягнення учнів за допомогою ІКТ);

- предметно-орієнтована компетентність (здатність застосовувати готові електронні продукти у навчанні) [8]. 
Модель інформаційної компетентності за О. Б. Модуліною (2008) пов'язана 3 освоєнням і використанням ІКТ у навчанні. Автор виділяє п'ять компонентів моделі, що поступально формують портрет компетентного у сфері ІКТ учителя: від «освоєння інструментальних можливостей ІКТ» до «нової організації освіти на підставі ресурсів $\mathrm{IKT} \gg[19]$.

П. П. Грабовський (2008) бачить інформаційну компетентність учителя середньої школи як інтегроване утворення, яке включає:

- операційну компетентність (знання, уміння, досвід та вирішення проблем, які пов'язані з використанням ІКТ);

- $\quad$ методичну компетентність (знання про можливості використання ІКТ для вдосконалення навчання по предмету);

- $\quad$ загальнокультурну компетентність, пов'язану з упровадженням IКТ в освіту;

- компетентність у питаннях збереження здоров'я під час використання IKT [20].

Л. С. Петухова (2008) розглядає набір інформатичних компетентностей учителя початкових класів як «системний обсяг знань, умінь і навичок набуття, перетворення, передавання та використання інформації у різних галузях людської діяльності для якісного виконання професійних функцій» [9].

Інформаційно-технологічною називає дану компетенцію П. В. Беспалов (2006) та приводить так її компоненти [21]:

- знання, уміння й навички в галузі інформатики;

- особистісна мотивація, значимість, задоволеність;

- датність розв’язувати професійні завдання різного ступеня складності;

- загальні інтелектуальні здатності, рефлексивність діяльності.

Аналогічну за властивостями О. М. Спірін (2009) інформатичну компетентність пропонує розуміти як «підтверджену здатність особистості використовувати інформаційні технології для гарантованого донесення та опанування інформації 3 метою задоволення власних індивідуальних потреб і суспільних вимог щодо формування загальних та професійно-спеціалізованих компетентностей людини» [15]. Автор наводить також визначення інформаційно-технологічної компетентності, яке подібне визначенню інформатичної компетентності в роботі Л. Є. Петухової [9]. 
В. Г. Риндак і О. С. Полянська (2007), використовуючи термін «IКТкомпетентність», формують портрет ІКТ-компетентного вчителя:

- $\quad$ здійснює пошук матеріалів для навчання, у тому числі, за допомогою Інтернету;

- уміє презентувати навчальні матеріали за допомогою різних комп'ютерних засобів;

- перебуває у професійних Інтернет-співтовариствах, підвищує свою кваліфікацію шляхом спілкування в мережі;

- розробляє системи оцінювання знань учнів;

- $\quad$ с с $\quad$ вворює власні електронні навчальні посібники;

- $\quad$ створює бази даних навчального призначення;

- застосовує готові мультимедійні програми в навчально-виховних цілях;

- управляє навчально-виховним процесом за допомогою комп'ютерних технологій [22].

Згідно з підходом ЮНЕСКО (2001, 2004) [23, 24] підготовку вчителів до використання IКТ необхідно проводити у двох напрямках. Перший ("learning-to-use") стосується придбання навичок використання IКТ для особистих потреб і професійної діяльності, другий ("using-to-learn") - фокусується на способах інтеграції IКТ у навчальний процес і підвищенні ефективності засвоєння базових знань і вмінь учнів за рахунок використання IКТ.

У документі ЮНЕСКО «Інформаційні й комунікаційні технології у навчанні: навчальні плани для середньої школи й програми підготовки викладачів» (2005) визначено сім груп ключових ІКТ-компетенцій учителів, що характеризуються як «здатності» [25]:

- визначати найбільш ефективні інструменти IКТ для досягнення навчальних цілей і спонукання учня до навчання;

- управляти навчальним процесом, використовуючи командний принцип;

- забезпечувати різноманітність i оцінювати якість (читабельність, структуру, відповідність цілям) мультимедійних презентацій у навчальному процесі;

- оцінювати якість готових мультимедійних навчальних ресурсів, у тому числі, їх внесок в індивідуальне навчання школярів; 
• $\quad$ сприяти учням у пошуку матеріалів за допомогою Інтернет та інших ресурсів;

• спілкуватися в професійному середовищі за допомогою ІКТ;

- $\quad$ максимально ефективно працювати з ІКТ, брати участь у нових проектах, постійно розвиватися і підвищувати свій професійний рівень.

У 2008 р. групою експертів ЮНЕСКО сформульований розгорнутий перелік складових ІКТ-компетентності вчителів початкової й середньої освіти на підставі трьох підходів (технічної грамотності, поглиблення й створення знань) і шести освітніх модулів (політика, програма й оцінка, педагогіка, IКТ, організація й адміністрація, професійне зростання) [26].

I. Б. Милова (2004) пропонує використовувати термін «інформаційнотехнологічна компетентність» під час розгляду питань підготовки вчителів початкових класів до використання інформаційних і комунікаційних технологій i розвитку відповідних професійних ІКТ-здатностей [27].

Орієнтуючись на особистісні властивості педагога й необхідність мотиваційної складової навчання, Л. Д. Ситнікова (2010) визначає ІКТ-компетентність вчителя початкових класів як особисту якість, що відбиває готовність і здатність учителя початкових класів вирішувати професійні завдання з використанням засобів IКТ у досягненні основної мети професійної діяльності - створення умов для позитивного розвитку особистості молодшого школяра в інформаційнім суспільстві [28].

Низка вітчизняних фахівців [11] розглядає компетентності в галузі інформаційних і комунікаційних технологій як ключові (базові) і формулює перелік відповідних навичок вчителя:

- $\quad$ використовувати IКТ у навчанні й повсякденному житті;

- раціонально використовувати комп'ютер i комп'ютерні засоби в розв'язуванні завдань, які пов'язані 3 обробкою інформації, ऑii пошуком, систематизацією, зберіганням, поданням й передаванням;

- будувати інформаційні моделі й досліджувати їх за допомогою IКТ;

- давати оцінку процесу й результатам технологічної діяльності.

У рекомендаціях Агенції з підвищення кваліфікації вчителів Великобританії (Teacher Training Agency) [29] IКТ-компетентності вчителя характеризуються як знання: 
- $\quad$ коли і як використовувати IКТ для викладання свого предмету, і коли IКТ не потрібні;

• як застосовувати IКТ в навчанні всього класу;

• $\quad$ як IКТ можуть допомогти у плануванні навчального процесу, підготовки до уроків, вибору й організації ресурсів IКТ;

- $\quad$ як оцінювати діяльність учнів під час роботи з IKT;

- як за допомогою IКТ підвищувати свій професійний рівень, обмінюватися досвідом і спрощувати бюрократичні процедури.

Принципи підготовки майбутніх педагогів до використання IKT, які сформульовані Суспільством інформаційної технології й навчання вчителів (Society for Information Technology and Teacher Education, SITE) [29], можна трактувати як ІКТ-компетентності, тобто здатності й навички:

- освоювати IКТ, самостійно знаходити способи застосування засобів IКТ у викладацькій діяльності;

- використовувати IКТ для розв'язування конкретних навчальних завдань, розуміти педагогічні підстави для використання IКТ;

- освоювати цілісні системи навчання на основі IКТ, застосовувати IКТ у традиційному та інших видах навчання.

Міжнародне суспільство із застосування технології в освіті (International Society for Technology in Education, ISTE) формулює ключові IКТ-компетенції вчителя так [30]:

- сприяти навчанню і творчості учнів за допомогою IКТ;

• планувати $з$ використанням цифрових технологій процес навчання, що має бути спрямований на індивідуальні особливості учнів, розвиток їхніх знань, умінь i навичок;

• демонструвати знання, уміння й навички сучасного фахівця, у тому числі, 3 використанням IКТ;

• розуміти глобальні соціальні питання й загальнокультурні норми цифрового століття, відповідати цим нормам у професійній діяльності.

Про професійно-педагогічну ІКТ-компетентність в різних іï проявах говориться також в інших публікаціях [наприклад, 31-33]. Навчальні програми з умовною назвою «Використання IКТ у навчальному процесі початкової школи» націлені на 
підготовку як студентів педагогічних вишів, так і вчителів, що проходять курси підвищення кваліфікації в установах післядипломної освіти.

Необхідність набуття ІКТ-компетентності майбутніми й теперішніми педагогами підкріплюється низкою нормативних актів України, міжнародними проектами (European Computer Driving License, ECDL; IT Professional Development System for Teachers, Teach-it.net; Intel - Навчання для майбутнього; Microsoft - Партнерство в навчанні й ін.) і численними науковими працями. Зокрема, питання формування компетентності вчителя початкових класів в галузі ІКТ розглядаються в роботах [29, 34-46 та ін.]. При цьому найчастіше базові ІКТ-компетентності пов'язують зі здатністю вчителя викладати інформатику в початкових класах [наприклад, 40, 43] i (або) проведенням інтегрованих уроків з ІКТ-підтримкою, де комп'ютер є засобом діяльності учня [наприклад, 29, 41, 42].

Аналіз доступної літератури не виявив у змісті IKTкомпетенцій/компетентностей учителя початкових класів зв'язку із суб'єктом навчання з обмеженими можливостями, зокрема, з порушеннями зору. У той же час, сучасні тенденції до інтеграції та інклюзї дітей із захворюваннями органу зору в масові школи диктують необхідність формування блоку спеціальних компетентностей у сфері IКT, які пропонується назвати тифлоінформаційними. Спеціальні ІКТ-компетентності згідно 3 принципом педагогічної спрямованості повинні носити суб'єктно-орієнтований характер, тобто всебічно враховувати індивідуальні особливості учня з порушенням зору.

Сутність і структура тифлоінформаційних компетентностей учителя початкових класів грунтується на особливостях зорового сприйняття та розвитку дітей 3 порушенням зору; характерних для форм організації навчання цільової групи учнів; сучасних підходах до використання ІКТ у початкових класах; методиках навчання дітей з дефектами зору з використанням IКТ; вимогах до програмного забезпечення навчального призначення для учнів з ослабленим зором.

Тифлоінформаційні компетентності сучасного вчителя початкових класів у цій роботі розглядаються як набір таких здатностей:

- знати, кого вчиш (здатність визначити місце дитини в класифікації дітей 3 порушенням зору; здатність оцінити психофізіологічні особливості учня); 
- знати, як учити, використовуючи IКТ опосередковано (знання небезпек, що надходять від комп'ютера, та розуміння їх впливу на здоров'я і розвиток дітей 3 порушенням зору; здатність розробляти суб'єктно-орієнтовані друковані дидактичні матеріали; здатність розробляти індивідуальне середовище навчання 3 підтримкою IКТ для кожної дитини; здатність оцінити якість педагогічних програмних засобів; здатність адаптувати наявні й створювати власні педагогічні програмні засоби; здатність управляти процесом навчання із використанням IКТ);

- знати, як учити, використовуючи IКТ безпосередньо (здатність уникати небезпек, що надходять від комп’ютера, під час навчання дітей з порушенням зору; знання методик, методів, прийомів ведення уроків з ІКТ-підтримкою для учнів початкових класів з порушенням зору; здатність оцінити педагогічну доцільність використання IКТ у навчанні; здатність вибирати й застосовувати IКТ-засоби в рамках сформульованого дидактичного завдання 3 урахуванням особливостей суб'єкта навчання);

- знати, як учитися, тобто підвищувати свій кваліфікаційний рівень (здатність свідомо здобувати нові знання шляхом пошуку матеріалів у мережі Інтернет; здатність ініціативно обмінюватися досвідом у професійних співтовариствах; здатність відслідковувати актуальні події світового, державного й регіонального масштабу, що стосуються підтримки навчання учнів початкових класів 3 використанням ІКТ).

Завданням для подальших досліджень $є$ розробка методик формування тифлоінформаційних компетентностей учителя початкових класів.

\section{Список використаних джерел}

1. Солнцева Л. И. Современная тифлопедагогика и тифлопсихология в системе образования детей с нарушениями зрения/ Л. И. Солнцева. - М.: ПолиграфСервис, 1999. - 180 с.

2. Дегтяренко T. M. Комплексна система корекційно-реабілітаційної роботи в дошкільному закладі для дітей з порушеннями зору: дис... канд. пед. наук: 13.00.03/ Дегтяренко Тетяна Миколаївна. - К., 2005. - 252 с.

3. Cattani $R$. Towards a fully inclusive and effective education for blind and partially sighted people in the light of the UN Convention on the Rights of Persons with Disabilities: a historical paradigm shift [WWW-Document]/ Rodolfo Cattani// Proceedings 
from 7th European Conference of ICEVI "Living in a Changing Europe" (Dublin, Ireland, $5^{\text {th }}$-10th July 2009). - - Accessible from: http://www.icevieurope.org/dublin2009/ICEVI2009_Abstract_503.doc.

4. Образование лиц с ограниченными возможностями в контексте программы ЮНЕСКО «Образование для всех»: Опыт России: Аналитический обзор/ [Л. В. Андреева, Д. И. Бойков, Е. Ф. Войлокова и др.]; под ред. акад. Г. А. Бордовского. - СПб.: Изд-во РГПУ им. А. И. Герцена, 2007. - 81 с.

5. Малофеев Н. Н. Модернизация системы специального образования: проблемы коррекции, реабилитации, интеграции/ Н. Н. Малофеев// Материалы Междунар. науч.-практ. конф. по проблемам интегрир. обучения лиц с огранич. возможностями здоровья (с особыми образоват. потребностями) «Интегративные тенденции современного специального образования» 26-28 нояб. 2003, Минск, Беларусь/ Институт коррекционной педагогики PAO (Москва). - М.: Полиграф Сервис, 2003. - С . 12-28.

6. Кукушкина О. И. В городском дворе: Цикл специализированных компьютерных программ «Картина мира» [Электронный ресурс] / О. И. Кукушкина, Е. Л. Гончарова, Т. К. Королевская. - М.: Полиграф-сервис, 2002. - Прикладная программа (75 Mb). - 1 электрон. опт. диск (CD-ROM).

7. Хуторской A. В. Технология проектирования ключевых и предметных компетенций [Электронный ресурс]/ А. В. Хуторской// Интернет-журнал «Эйдос». 2005. - 12 декабря. - Режим доступа: http://www.eidos.ru/journal/2005/1212.htm. — В надзаг: Центр дистанционного образования «Эйдос», e-mail: list@eidos.ru.

8. Литвинова C. компетентності (ІКК) вчителів-предметників/ С. Г. Литвинова// Інформаційні технології i засоби навчання: електронне наукове фахове видання [Електронний ресурс] / Гол. ред.: В. Ю. Биков; Ін-т інформ. технологій і засобів навчання АПН України, Ун-т менеджменту освіти АПН України. — 2008. — № 1(5). — Режим доступу: http://www.nbuv.gov.ua/e-journals/ITZN/em5/emg.html.

9. Петухова Л. С. Дидактико-процесуальне забезпечення формування інформатичних компетентностей майбутніх учителів/ Л. Є. Петухова// Інформаційні технології і засоби навчання: електронне наукове фахове видання [Електронний ресурс] / Гол. ред.: В. Ю. Биков; Ін-т інформ. технологій і засобів навчання АПН 
України, Ун-т менеджменту освіти АПН України. — 2008. — № 3(7). — Режим доступу: http://www.nbuv.gov.ua/e-journals/ITZN/em7/emg.html.

10. Семенов А. Л. Роль информационных технологий в общем среднем образовании/ А. Л. Семёнов. - М.: Изд-во МИПКРО, 2000. — 12 с.

11. Компетентнісний підхід у сучасній освіті: світовий досвід та українські перспективи: Бібліотека 3 освітньої політики/ [Н. М. Бібік, Л.С. Ващенко, О. І. Локшина, О. В. Овчарук та ін.], під заг. ред. О. В. Овчарук. - К.: «К.І.С.», 2004. $112 \mathrm{c}$.

12. Жалдак M. I. Про деякі методичні аспекти навчання інформатики в школі та педагогічному університеті/ M. I. Жалдак// Наукові записки Тернопільського національного університету ім. В. Гнатюка. Серія: Педагогіка. - 2005. - № 6 . C. 17-24.

13. Жалдак M. I. Деякі методичні аспекти навчання інформатики в школі і педагогічному університеті/ M. I. Жалдак// Комп'ютерно-орієнтовані системи навчання. Випуск 9. Науковий часопис. - Київ.: НПУ ім. М .П. Драгоманова. 2005. - C. 3-14.

14. Фридланд А. Я. Информатика и ее сущность (место информатики в современном мире)/ А. Я. Фридланд// Информатика и образование. - 2008. - № 4. - C. 76-88.

15. Спірін O. M. Інформаційно-комунікаційні та інформатичні компетентності як компоненти системи професійно-спеціалізованих компетентностей вчителя інформатики/ О. М. Спірін// Інформаційні технології і засоби навчання: електронне наукове фахове видання [Електронний ресурс] / Ін-т інформ. технологій i засобів навчання АПН України, Ун-т менеджменту освіти АПН України; гол. ред.: В. Ю. Биков. - 2009. - № 5(13). - Режим доступу: http://www.ime.eduua.net/em13/emg.html.

16. Зайщева О. Б. Формирование информационной компетентности будущих учителей средствами инновационных технологий: автореф. дис. на соискательство науч. степени канд. пед. наук: спец. 13.00.08 «Теория и методика профессионального образования»/ О. Б. Зайцева. - Брянск, 2002. - 19 с.

17. Тришина С. В. Информационная компетентность специалиста в системе дополнительного профессионального образования [Электронный ресурс]/ 
С. В. Тришина, А. В. Хуторской// Интернет-журнал «Эйдос». — 2004. — 22 июня. Режим доступа: http://www.eidos.ru/journal/2004/0622-09.htm. — В надзаг: Центр дистанционного образования «Эйдос», e-mail: list@eidos.ru.

18. Науменко О. М. Готовність викладача коледжу до застосування комп’ютерно орієнтованих засобів навчання [Електронний ресурс]/ О. М. Науменко// Інформаційні технології і засоби навчання: електронне наукове фахове видання / Ін-т інформ. технологій і засобів навчання АПН України, Ун-т менеджменту освіти АПН України; гол. ред.: В. Ю. Биков. - 2009. - № 4(12). - Режим доступу: http://www.nbuv.gov.ua/e-journals/ITZN/em12/emg.html.

19. Модулина О. Б. Информационная компетентность педагога как ресурс развития образовательной практики/ О. Б. Модулина// Информатика и образование. - 2008. - № 8. - С. 91-93.

20. Грабовський П. П. Інформаційна компетентність учителя середньої школи/ П. П. Грабовський// Вісник Житомирського державного університету імені Івана Франка. — 2008. — №37. - С. 118-123.

21. Беспалов П. В. Акмеологическая концепция развития информационнотехнологической компетентности государственных служащих: автореф. дисс. на соискание ученой степени доктора пед. наук: спец. 19.00.13 «Психология развития, акмеология»/ П. В. Беспалов. - М., 2006. — 66 с.

22. Рындак В. Г. Электронный лабораторный практикум как средство формирования ИКТ-компетентности будущего учителя [Электронный ресурс]/ В. Г. Рындак, Е. Е. Полянская// Интернет-журнал «Эйдос». — 2007. — 30 сентября. Режим доступа: http://www.eidos.ru/journal/2007/0930-1.htm. — В надзаг: Центр дистанционного образования «Эйдос», e-mail: list@eidos.ru.

23. Perraton, H. Teacher Education Through Distance Learning: Technology Curriculum - Cost - Evaluation (Summary of Case Studies)/ Perraton, H, Robinson, B and Creed, C. - Paris: UNESCO, 2001. - Pp. 33-34.

24. Building Capacity of Teachers/Facilitators in Technology-Pedagogy Integration for Improved Teaching and Learning: Final Report/ UNESCO. - Bangkok: UNESCO Bangkok, 2004. - $72 \mathrm{p}$.

25. Информационные и коммуникационные технологии в образовании: учебные планы для средней школы и программы подготовки преподавателей/ 
[Джонатан Андерсон, Том ван Вирт, Алексей Семенов и др.]; рус. изд. под ред. Алексея Семенова; ред. рус. пер. Александр Гиглавый. - Division of Higher Education, ЮНЕСКО, 2005. - 165 c.

26. Нормы ЮНЕСКО по компетентности учителей в использовании ИКТ. Руководящие принципы (UNESCO's ICT Competency Standards for Teachers. The Standards (RU)) [Электронный ресурс]/ [Пер. с английского]. - ЮНЕСКО. - 2008. - Режим доступа: дttp://cst.unescoci.org/sites/projects/cst/The\%20Standards\%20RU/Forms/AllItems.aspx.

27. Мылова И. Б. Подготовка специалистов в области информатизации начального образования/ И. Б. Мылова// Информатика и образование. - 2004. - №9. - С. 83-88.

28. Ситникова Л. Д. Формирование информационно-коммуникационной компетентности будущих учителей начальных классов/ Л. Д. Ситникова// Информатика и образование. - 2010. — № 2. - С. 97-102.

29. Информационные и коммуникационные технологии в подготовке преподавателей. Руководство по планированию/ [Семенов А. Л, Аллен Н., Андерсон Д. И др.]; под ред. А. Л. Семенова. — Division of Higher Education, ЮНЕСКО, 2005. $-284 \mathrm{c}$.

30. The ISTE National Educational Technology Standards (NETS•T) and Performance Indicators for Teachers [WWW-Document]// [ISTE (International Society for Technology in Education) Web site (http://www.iste.org)]. - 2008. - Accessible from: http://www.iste.org/Content/NavigationMenu/NETS/ForTeachers/2008Standards/NETS_T_ Standards_Final.pdf.

31. Хеннер E. K. Информационно-коммуникационная компетентность учителя: структура, требования и система измерения/ Е. К. Хеннер, А. П. Шестаков// Информатика и образование. - 2004. - №12. - С. 6-11.

32. Рыљжова Н. И. Концептуальные линии развития содержания обучения, направленного на формирование информационно-аналитической компетентности специалиста/ Н. И. Рыжова, В. И. Фомин, Е. В. Филимонова// Информатика и образование. - 2008. - № 12. - С. 96-101. 
33. Адольф B. A. Методологические подходы к формированию информационной культуры педагога/ В. А. Адольф, И. Ю. Степанова// Информатика и образование. - 2006. - № 1. - С. 2-5.

34. Кондратова В. В. Модернізація підготовки вчителів початкових класів до проведення уроків з комп'ютерною підтримкою/ В. В. Кондратова// Педагогічний вісник: науково-методичний щоквартальний журнал. - 2007. - №1. - С. 28-32.

35. Левшин М. М. Використання інформаційних технологій у навчальновиховному процесі початкової школи/ М. М. Левшин, О. П. Муковіз // Сільська малокомплектна школа: теоретико-методологічний аспект: Навчальний посібник. K., 2005. - C. 33-43.

36. Мазоха Д. С. Інноваційні технології формування професіоналізму вчителя в системі безперервної освіти/ Д. С. Мазоха// Вісник Житомирського державного університету імені Івана Франка. - 2005. — №25. - С. 23-26.

37. Шапошникова I. M. Комп'ютерна грамотність як умова ефективного розвитку суспільства / I. М. Шапошникова, Л. Л. Макаренко// Наука і сучасність: збірник наукових праць. Т. 38 / НПУ ім. М .П. Драгоманова; Редкол. М. І. Шкіль (голова) та ін. - Київ, 2003. - С. 159-164.

38. Гунько С. О. Формування системи знань про інформаційні технології у майбутніх вчителів початкових класів: автореф. дис. на здобуття наук. ступеня канд. пед. наук: спец. 13.00.01 «Теорія та історія педагогіки»/ С. О. Гунько. - Київ, 1999. $20 \mathrm{c}$.

39. Шиман О. I. Формування основ інформаційної культури майбутніх учителів початкової школи : автореф. дис. на здобуття наук. ступеня канд. пед. наук: 13.00.02 «Теорія та методика навчання інформатики»/ О. І. Шиман. — К, 2005. $20 \mathrm{c}$.

40. Информатика в играх и задачах для 1, 2, 3 и 4 кл.: Методические рекомендации для учителя/ [Горячев А. В., Волкова Т. О., Горина К. И. и др.]. - М.: Баласс, 1998. - 199 с.

41. Информационные технологии на уроках в начальной школе/ [сост. О. В. Рыбъякова]. - Волгоград: Учитель, 2008. — 223 с.

42. Коломієць A. M. Теоретичні та методичні основи формування інформаційної культури майбутнього вчителя початкових класів: автореф. дис. на 
здобуття наук. ступеня д-ра пед. наук.: спец. 13.00.04 «Теорія і методика професійної освіти»/ А. М. Коломієць. - К., 2008. - 42 с.

43. Суховірський О. В. Підготовка майбутнього вчителя початкової школи до використання інформаційних технологій: дис. ... канд. пед. наук: 13.00.04 автореф. дис. на здобуття наук. ступеня канд. пед. наук: 13.00.04 «Теорія та методика професійної освіти»/ О. В. Суховірський / Інститут педагогіки АПН України. - К., 2005. $-20 \mathrm{c}$.

44. Смирнова I. М. Формування інформаційної культури майбутніх учителів початкових класів: автореф. дис. на здобуття наук. ступеня канд. пед. наук: 13.00.04 «Теорія та методика професійної освіти»/ I. М. Смирнова. - Кіровоград, 2004. $20 \mathrm{c}$.

45. Снігур О. М. Формування вмінь використовувати засоби інформаційних технологій у майбутній професійній діяльності вчителя початкової школи: дис. на здобуття наук. ступеня канд. пед. наук: 13.00.09 «Теорія навчання»/ О. М. Снігур. — K., 2007. - 22 c.

46. Макаренко Л. Л. Комп'ютерна грамотність як складова професійної підготовки майбутніх учителів початкової школи: автореф. дис. на здобуття наук. ступеня канд. пед. наук: 13.00 .04 «Теорія та методика професійної освіти»/ Л. Л. Макаренко. - К., 2007. - 22 с.

\section{ТИФЛОИНФОРМАЦИОННЫЕ КОМПЕТЕНТНОСТИ СОВРЕМЕННОГО УЧИТЕЛЯ НАЧАЛЬНЫХ КЛАССОВ}

Косова $\boldsymbol{E}$. $\boldsymbol{A}$.

\section{Аннотация}

Тенденции к обучению детей с нарушением зрения в массовых школах с определяющим значением информационно-коммуникационных технологий (ИКТ) в обучении таких детей предъявляют требования к соответствующей подготовке учителей начальных классов. Целью статьи является анализ подходов к формулированию понятия компетенции/компетентности в области ИКТ с последующим определением содержания специальных компетентностей учителей начальных классов, которые предлагается назвать тифлоинформационными. На основании анализа литературы, сделан вывод об отсутствии в содержании ИКТкомпетенций/компетентностей связи с субъектом обучения с нарушением зрения и 
сформулирован перечень тифлоинформационных компетентностей учителя начальных классов. Задачей для дальнейших исследований является разработка методик формирования соответствующих компетентностей.

Ключевые слова: компетентности в сфере ИКТ, дети с нарушением зрения, учителя начальных классов, тифлоинформационные компетентности.

\section{MODERN PRIMARY SCHOOL TEACHER'S TIFLOINFORMATION COMPETENCES}

\section{Kosova $K$.}

\section{Resume}

Tendencies of integration of visual impaired children to the mass schools as well as significant value of information-communication technologies (ICT) in the education of these children require corresponding training of primary school teachers. The purpose of this article is to analyse the approaches to the concept of ICT-competence with further definition of primary school teacher's tifloinformation competences. Literature analysis has discovered that there is no connection between ICT-competences and pupil with visual impairments yet. As a result, the list of primary school teacher's tifloinformation competences was formulated. The objective of further investigations consist in the development of techniques essential for creation of corresponding competences.

Keywords: competences in ICT, children with visual impairments, primary school teachers, tifloinformation competences. 